IZA DP No. 6487

“I Wish I Had 100 Dollars a Month ..." The Intergenerational Transfer of Poverty in Mongolia

Francesco Pastore

April 2012 


\title{
"I Wish I Had 100 Dollars a Month ..." The Intergenerational Transfer of Poverty in Mongolia
}

\author{
Francesco Pastore \\ Seconda Università di Napoli \\ and IZA
}

\author{
Discussion Paper No. 6487 \\ April 2012
}

IZA
P.O. Box 7240
53072 Bonn
Germany

Phone: +49-228-3894-0

Fax: +49-228-3894-180

E-mail: iza@iza.org

\begin{abstract}
Any opinions expressed here are those of the author(s) and not those of IZA. Research published in this series may include views on policy, but the institute itself takes no institutional policy positions.

The Institute for the Study of Labor (IZA) in Bonn is a local and virtual international research center and a place of communication between science, politics and business. IZA is an independent nonprofit organization supported by Deutsche Post Foundation. The center is associated with the University of Bonn and offers a stimulating research environment through its international network, workshops and conferences, data service, project support, research visits and doctoral program. IZA engages in (i) original and internationally competitive research in all fields of labor economics, (ii) development of policy concepts, and (iii) dissemination of research results and concepts to the interested public.
\end{abstract}

IZA Discussion Papers often represent preliminary work and are circulated to encourage discussion. Citation of such a paper should account for its provisional character. A revised version may be available directly from the author. 


\section{ABSTRACT \\ "I Wish I Had 100 Dollars a Month ..." The Intergenerational Transfer of Poverty in Mongolia*}

This paper aims to study the mechanisms of the intergenerational transfer of poverty: it considers household poverty as a risk factor for youth poverty. The study is based on a unique, nationally representative School-to-Work Transition survey carried out in 2006 in Mongolia, one of the 50 poorest countries of the world. A young person born in a household living out of $\$ 1$ a day has a ceteris paribus probability about 4 times greater of dropping out of school, 2.5 times greater of being educationally marginalized and 20 times greater of being a working poor than a contemporary born in a family living out of more than $\$ 3$ a day.

JEL Classification: D63, H24, J62, I32, P36

Keywords: transition from plan to market, poverty and inequality, intergenerational transfer of poverty, Mongolia

Corresponding author:

Francesco Pastore

Seconda Università di Napoli

Faculty of Law

Via Mazzocchi, 5

I-81055 Santa Maria Capua Vetere (CE)

Italy

E-mail: francesco.pastore@unina2.it

\footnotetext{
* "Se potessi avere mille lire al mese ..." (En.Tr.: "I wish I had 1000 liras per month") is the refrain of a famous 1939 Italian song representing the aspirations of the country's population at that time. The Euro equivalent of 1000 liras is about $€ 0.50$. This paper further elaborates on findings of research work carried out as part of two projects implemented together with the ILO in 2007 (Project "Promoting decent and productive work for young women and men in Mongolia" within the framework of the ILO/Korea Partnership programme.) and the UNESCO in 2011. A special thank is due to all those who have carried out the Mongolian School to Work Transition Survey. In addition, the author wishes to thank Claire Harasty, Diego Rei and Cameron Stuart for useful comments on background research. This notwithstanding, the usual disclaimer applies.
} 


\section{Introduction}

Surprisingly, in Mongolia, poverty is a relatively recent phenomenon. In fact, as Mearns (2004, p. 110) noted, poverty is thought to have been virtually unknown in Mongolia until 1990, and inequality was certainly very low. By 1995, however, 36 per cent of the population was estimated to fall below the poverty line, and inequality had risen significantly. Since then, the country has scored as one of the fifty poorest countries in the world. Comparison of Mongolia's ranking on the UNDP-based Human Development Index (HDI) and Human Poverty Index (HPI) seems to confirm this. In 2006, it ranked 116 on the former while only 42 on the latter. In addition, while the HDI ranking has improved in recent years, essentially due to a fast growth process, the HPI ranking has dropped further. Poverty and inequality represent important constraints for future development by hindering the expansion of internal demand, on one hand, and by reducing the competitiveness of the country in international markets, on the other, via a reduction of the educational and employment opportunities of the younger generation (UNDP, 2006; and 2007).

Any society develops pervasive mechanisms of intergenerational transfer of income. This paper aims to supply several measures of poverty and inequality in Mongolia, one of the poorest and yet least studied countries of the world. Indirectly, the paper shows that chances in life of Mongolian children are meagre especially when belonging to poor households. In fact, important constraints seem to affect the supply of education, especially in rural areas. It means that the existing distribution of income and wealth heavily influences access to education and hence a large part of the youth is bound to remain in a poverty trap for generations, unless help is provided from (internal or external) policy makers.

This paper asks and answers a number of questions regarding the generating mechanism of poverty in the country. First, it aims to measure the extent of poverty and inequality in the country by using different indicators. It also asks what the threshold income is, below which policy makers are sure that money transfers will reduce the degree of income inequality and poverty. Second, it attempts to assess the extent of the intergenerational transfer of poverty by looking at the 
consequences of extreme poverty among young people, here defined as based on the Millennium Development Goals of $\$ 30$ and $\$ 60$ a month. In other words, the paper attempts to assess the existence of poverty driven constraints on the probability to invest in education and to find a job that does not lead to working poverty. We do so by estimating the impact of belonging to the extreme poverty households on the probability of: a) dropping out of school before achieving primary and low secondary (compulsory) education; b) of being educationally marginalized; c) of experiencing working poverty. Our findings confirm the hypothesis that all these decisions are a consequence of extreme poverty and, therefore, the most extreme form of intergenerational transfers of human capital and social status.

The analysis is based on a unique, nationally representative, School-to-Work Transition Survey (SWTS since now)of young people aged 15-29 years carried out in 2006 by the National Statistical Office of Mongolia with the International Labour Office's (ILO) financial and technical assistance. It includes about 4.585 households and 6,100 young (15-29 years) people, representing $0.75 \%$ of the reference population.

The outline of this paper is as follow. Section one motivates the paper, while section two shortly discusses methodology and data. Section three provides measures of inequality and poverty among young Mongolian's households. The following three sections study the determinants of dropouts, of educational marginalization and of working poverty respectively. Some concluding remarks follow.

\section{Motivation}

In the early 2000s, the Government of Mongolia (2001, p. 4) noted that from the sample surveys (LSMS, PLSA) available at that time, five categories of population were more likely to fall into poverty; (i) single parent headed households with many children, (ii) households holding less than 100 heads of livestock (depending on size and structure of households), (iii) unemployed, (iv) uneducated (without basic education), (v) vulnerable groups (elderly, disabled, street children and orphan children). 
The aim of this paper is to contribute to the identification of the most vulnerable categories of young people for better design and targeting of anti-poverty action plans. The specific focus of the analysis is identifying the extent to which youth outcomes in life are affected by their parents' outcomes. More specifically, we study the mechanisms that generate the intergenerational transfer of poverty, by looking at household poverty as a risk of youth poverty, as measured using different indicators of youth disadvantage, such as dropping out of school involuntarily before completing high secondary school, being educationally marginalized - namely holding an educational level that is sufficiently lower than average to feel marginalized in society - and being working poor, namely working for a salary that is below the poverty line.

A new strand of research is addressing the issue of understanding the size and determinants of the intergenerational transfer of human capital and poverty in both developed and developing countries. In their study on 42 countries of all continents, for instance, Hertz et al. (2007) do not include Mongolia. They do provide however information on the extent of intergenerational transfers on comparable Asian countries. They find that the ten Asian countries included in the sample have an average intergenerational schooling correlation of 0.35 , although three of them appear among the five lowest (East Timor (0.14), Rural China (0.20), and Pakistan (0.27)) and six among the lowest ten (add Bangladesh, Nepal, and Malaysia).

Despite its position as one of the 50 poorest countries of the world, Mongolia is almost invariably excluded from existing analyses. Nonetheless, although being a recent phenomenon, poverty might be a condition in Mongolia in which households will remain trapped for generations. The family is the first societal unit in which young people live. It is therefore the first social institution towards which young people direct their expectations about adult life. This is particularly true in countries where social mobility is low and the economic structure is stable over time, as it is the case in contemporary Mongolia.

In principle, due also to the low development of the educational system and other institutions aimed at equalizing opportunities for all, family background is expected to influence many aspects of young people's life in Mongolia. Assessing the extent to which intergenerational transfers of wealth, 
income, education and also employment opportunities from parents to their children happen is of great interest for better design of anti-poverty action plans.

The SWTS of Mongolia includes detailed information on parents' education, occupation and income levels on a large sample of young people, therefore providing an excellent testing ground to assess the extent of the intergenerational transfer of poverty. In particular, it allows studying the correlation between indicators of performance in education attainment and labour market outcomes between children and their parents.

It is expected that the educational level of fathers and mothers are important predictors of the probability that young people choose to study rather than working. Family background might prove an important predictor of the motivation of young people in pursuing their educational career. The rationale for this is to be found in the intergenerational transfer of preferences regarding the decision to invest in education, as ascertained by a large literature. Parents with a high educational achievement tend to weigh less the cost and more the benefit of education as compared to the rest of the population. Moreover, parents with a high level of education tend to have also higher incomes and therefore the cost of their children' education is relatively lower for them. Third, parents with a high educational attainment are more able to suggest their children the ways to use their higher level of education in the labour market, therefore, increasing the expected returns to education of their children. As a consequence of large intergenerational transfers of educational levels, we also expect to find a strong mechanism of intergenerational transfer of poverty. This is tested by studying the correlation between household poverty and being a working poor.

\section{The data used in the analysis}

The specifications adopted will be discussed in each section before implementation. This section aims to discuss a common factor of all analyses, namely the data used. It consists of an ad hoc (and unique) SWTS on 6871 young people aged 15-29 years carried out in 2006 by the National Statistical Office of Mongolia with the International Labour Office's financial and technical assistance ${ }^{i}$ 
The survey, which is nationally representative, was conducted through interviews of a sample that reflects the composition of the targeted population. The questionnaire captures both quantitative and qualitative information relating to a number of aspects (e.g. education and training, perceptions and aspirations in terms of employment and life goals and values, job search processes, family's influence in career choice, barriers to and supports for entry into the labour market, wage versus selfemployment preference, working conditions, etc. $)^{\mathrm{ii}}$.

The data allows controlling for a number of individual and environmental characteristics, namely gender, civil status, formal/informal employment, the status of migrant, union membership, past experiences of training, type of search method adopted to get the job, the industrial sector of activity, the location and whether one is living in a rural/urban area. Annex 1 provides a short description of the main features of the Mongolian educational system and its recent reforms. It also details the curricular years of education related to each type of diploma. Table A2.1 in Annex 2 provides descriptive statistics of the main variables used in the analysis.

\section{Household income inequality and poverty}

\subsection{Family background}

As an example of the information available in the SWT survey, Table 1 provides the distribution of fathers and mothers' occupations. Those young people, whose parents died, are unemployed or retired from the labour market are about $40 \%$ of the sample. The orphans of both parents are about $2.8 \%$ of interviewees. In addition, about $19 \%$ were fatherless and $6.1 \%$ were motherless. This is quite a high share considering the young age of the interviewees and mirrors the low life expectancy of Mongolians. About 4\% had both parents unemployed. The share of unemployed mothers or unemployed fathers is the same at about $10.4 \%$. Moreover, a minor share of those individuals whose father is unemployed and whose mother is not unemployed have also a mother that is retired or inactive. About $10.3 \%$ of young people have both parents retired. A larger share of mothers $(21.3 \%)$ than fathers $(15.3 \%)$ is retired, due to the lower retirement age of women compared to men and the higher mortality of men. The next largest share is constituted of young people whose father and/or 
mother is a herdsman. This is the most common occupation not only of parents, but also of children in Mongolia.

\section{[Table 1 about here]}

The educational level of fathers and especially of mothers is a good predictor of success not only in achieving higher education, but also greater employment opportunities. The distribution of educational levels of fathers and mothers is very similar (Table 2). A larger number of mothers have specialised secondary education and a larger number of fathers have basic or low secondary education. The closeness of the distribution of young people and their parents in terms of education attainment is prima facie evidence of strong intergenerational transfers and of stability of households' economic and social status.

\section{[Table 2 about here]}

\subsection{Inequality}

Table 3 provides some summary statistics relative to the household's monthly net income as measured in thousands of tughrik, the Mongolian currency ${ }^{i i i}$. The note to the table provides exchange rates for the dollar (US\$) and the Euro (€). The average income level of the households in the sample is TUGs 123,580 (US\$ 106.1 or $€ 78.9$ ). However, outliers might affect this average measure and it is convenient to exclude the lowest and highest values from the distribution to obtain a more reliable measure of the mean income. When excluding all the households belonging to the percentiles lower than the $10^{\text {th }}$ and $90^{\text {th }}$, then the average income equals TUGs 109,770 (US $\$ 94.3$ or $€ 70$ ). The median value, which is less affected by extreme values, equals TUGs 100,000 (US\$ 85.9 or $€$ 63.8), independent of the sample considered.

\section{[Table 3 about here]}

The average income does not explain the extent to which economic conditions change across households. The degree of inequality might affect the future growth prospect of the country, by reducing the opportunities of the largest number. Some measures of dispersion are already provided 
in Table 3, namely the minimum and maximum household income, as well as the standard deviation. These statistics show that inequality is relatively high. The richest household has an income that is 9,000 times higher than the poorest. However, there are only a few households with TUGs 0 and even fewer with TUGs 9,000. Therefore, this ratio might be misleading.

If the poorest (under the $10^{\text {th }}$ percentile) and the richest (above the $90^{\text {th }}$ ) households are excluded, then the ratio of the richest to poorest becomes 6.7. This is quite a high ratio: in fact, the lower the income level of a household, the higher the opportunity cost of education is and, therefore, the lower the probability of finding good jobs in the future is. ${ }^{\text {iv }}$

When the extreme cases are included, the standard deviation (the average difference from the mean income) is even greater than the mean value, suggesting that the mean does not completely represent the economic conditions of a large number of households. However, when the poorest and richest households are excluded from the sample, then, it appears that most households' income is between TUGs 58,120 (US\$49.9 or $€ 37$ ) and TUGs 161,450 (US\$138.6€103).

Other more complex measures of inequality are given in Table 4 for international comparisons. Whatever the index adopted, inequality is lower than average in the capital city than in rural areas. This is in line with Mearns (2004) and Morris and Bruun (2005) accounts of the evolution of rural areas after the privatisation of state and cooperative farms after the transition.

[Table 4 about here]

\subsection{Poverty}

One unanswered question of the previous section is: When is a household "poor"? The UNDP considers the share of the population living on less than US\$ 1 or 2 a day ${ }^{v}$. In the SWTS, the portion of the Mongolian population that lived on US\$ 30 a month or less is $10.1 \%$ and that living on US\$ 60 a month is $32.9 \%$. These shares are slightly lower than those reported by UNDP (2006, p. 293) as obtained based on average incomes relative to the period 1990-2004, suggesting an improvement in recent years. 
The simplest poverty line can be fixed at the income perceived by the household holding half of the median income, namely, in this case, TUGs 50,000 (US\$42.9 or $€ 31.9$ ). However, this measure is rough and many other measures have been used. Scholars have sought poverty lines that are of interest for policy makers aiming to reduce inequality and poverty. The latter are often interested in understanding when a redistributive policy from rich to poor households is actually able to alleviate poverty and reduce inequality.

The measures provided in Table 5 have been defined so as to allow money transfers from households above the poverty line to households below it, in order to be sure that such money transfer will reduce the overall degree of inequality and poverty (see Lambert and Lanza, 2006). In this way, according to recent literature, such transfers might also foster economic growth.

These poverty lines are relative to the actual household's distribution of incomes and can be defined with respect to different indices of inequality. The table provides measures relative to the Gini and the Theil inequality indices. Based on the Gini index, all those transfers from households in the percentiles above 63.3 to those in lower percentiles will reduce inequality. The corresponding benchmark income equals TUGs 120,000 (US\$103 or $€ 76.6$ ). The benchmark income based on the Theil index is slightly lower. The following columns of Table 5 bring further evidence of strong geographical differences. They suggest that, whatever the measure adopted, the threshold is much lower in rural than in urban areas. It is the highest in the capital city. In other words, poverty looks higher in rural areas, but this might also mirror the lower need of monetary means of payment there, as already noted, among others, in Mearns (2004, p. 118).

\section{[Table 5 about here]}

The abovementioned measures of poverty are all based on income levels. However, the national government can provide in-kind goods and commodities to poor households which are an important support for households in many developing and transition countries. Such aid can also come from external sources, such as foreign governments and international organizations. A more accurate measure of poverty should consider the availability of free health, educational and social services to 
the poorest households. Though not included in the declared income, these goods and commodities might alleviate the sense of deprivation and social exclusion due to poverty.

\section{Dropping out of school}

After documenting the degree of household poverty and inequality in our sample of youth, this section studies the phenomenon of dropping out of school, to assess the extent to which it is affected by the household characteristics and, in particular, household poverty.

The emphasis on investment in education, evidenced by low (or no) tuition fees, and on low or no risk of unemployment at all, evidenced by the ease to find a job after completing education, made formerly socialist countries traditionally feature high levels of educational attainment almost everywhere. A number of instruments had the important effect of reducing the cost of education, while the returns to education were essentially non-monetary in nature, in the sense that more educated people could have greater fringe benefits attached to their jobs, easier access to jobs requiring less fatigue and in a more favourable and friendly work environment, compared to manual workers. Instead monetary returns to education were relatively low, due to the low average level of incomes in many former socialist countries and also to their political emphasis on income inequality. This cultural heritage is still typical of most formerly socialist countries, where educational levels are traditionally, and still remain, high, as witnessed also by the high level of the HDI that they score.

Also Mongolia scores a relatively high ranking in terms of the HDI, as compared to other formerly socialist countries, despite the very low average income and the high share of population below the poverty line. One reason why the country has a relatively high HDI is the relatively high value of the education index as compared to other middle-income countries.

However, the available evidence based on the STWS suggests that Mongolia still under performs as compared to most former socialist countries and especially to FSU republics in terms of educational attainment. The Tables 6 and 7 provide detailed information on complete education attainment. Note that this data should be taken with the due caveats, considering that about $43 \%$ of 
the overall sample of interviewees is still in school at the time of the interview. The most reliable statistics are those relative to the oldest age segment (aged 25-29) most of whom (95.6\%) have already completed their education. The tables show that, in 2006, Mongolian young people had a level of education lower than the OECD average and also lower than other transitional economies.

\section{[Table 6 and 7 about here]}

The most striking fact to observe is that a low, but still noticeable share of $3.3 \%$ of the population aged 15-29 is uneducated. As it is typical also of other developing countries, this share of uneducated young people is more than twice higher among men than among women. As noted also in del Rosario (2005, p. 24), parents prefer boys to girls for herding.

The presence of a still large number of uneducated people in the young generation is particularly worrying if one considers that the vast majority of them live in urban areas. In fact, though the share of the uneducated living in rural areas is about three times higher in percentage terms (at $6.43 \%$ ) than in urban areas or in the province (aimag) or municipality (soum) centres, nonetheless, the larger population makes the overall size of the problem bigger in urban areas.

On the positive side, the share of young people that are uneducated is lower among the oldest segment, at $2.7 \%$, which might suggest that, in some way, at least part of the uneducated manage to achieve at least primary or basic education in their twenties ${ }^{\mathrm{vi}}$.

In addition, about $11-12 \%$ of the entire sample achieves only primary education and $20.4 \%$ of those aged 25-29 achieves only basic education, which is the compulsory level of education. In other words, $34.4 \%$ of the 25-29 group has compulsory education or below.

Table 8 provides the distribution of the uneducated by the reason why they dropped out from school before obtaining any diploma, by age and gender. The largest share of the uneducated left school because they did not enjoy it. This finding is very similar to that of del Rosario (2005, p. 27) and might be explained by a number of factors, such as bullying by the students' peers, lack of attention from teachers and in general the low quality of education and poor conditions of school infrastructures. Nonetheless, as del Rosario (2005, p. 65-66) finds, this result is to be compared with 
the attitude of young people on education and their drop out status: most dropouts, and their families, value education very much and feel sorry for the fact that they left school.

\section{[Table 8 about here]}

However, about $27 \%$ of the dropouts declare that they left school to take care of livestock. This share is significantly lower for women and for the young teenagers, suggesting that child labour related to herding is especially typical of boys and might reduce over time. Many women that remained uneducated did so because it was a choice of their parents. In fact, in many households, especially in rural areas, female children are involved in domestic chores.

Related to this is the high share, especially of young males who mention economic reasons. Overall, economic factors explain most of the reasons for dropping out of school, especially if one considers that the reason why many young people do not enjoy or do not like school is often related to the discrimination that they experience because of their poor cultural and social background ${ }^{\text {vii }}$.

The existence of the phenomenon of illiteracy in the after-compulsory school age is a worrying fact that educational policy should target. Integrating young people in compulsory education is the most effective way to increase the job finding rate and, therefore, reduce unemployment, crime, poverty and social exclusion in the long run.

The fight against illiteracy is a very hard one and should be the objective not only of educational policy itself, but also of employment policy and pro-poor policy. In fact, the most likely cause of illiteracy is child labour, namely the tendency by employers, sometimes also parents, to hire children during their compulsory schooling age to employ them in the highly labour intensive Livestock sector. In turn, child labour is an apparent consequence of poverty and confirms the worry that poverty might force too many young people into a trap. In order to survive, the poorest households might find it convenient (at least in the short run) to employ young children in low pay jobs to integrate their already very low income. Fighting child labour, perhaps with income support schemes for the poorest households is an important policy target for the government ${ }^{\mathrm{viii}}$.

The Mongolian Government is aware of the importance of this problem that has, in fact, exploded already in the early 1990s, soon after the beginning of the economic transition to a market economy 
and the ensuing emergence of poverty for many families, especially in rural areas. In fact, Mongolia has adopted a new definition of drop out and a new regulation to fight it in the Education Law of 2005. del Rosario (2005, p. 70) reports that the government has already adopted a number of interventions to reduce the drop out rate: a) abolition of the cost of school dormitories and food for children, through the allowance of subsidies; b) free school supplies in the amount of TUGs 16,000 (about \$13.7); c) the already noted implementation of adult learning for the uneducated.

However, first of all, it is a matter of concern whether the instruments adopted in the country are sufficient. According to del Rosario (2005), the Government is focusing on poverty/low income or lack of means of subsistence; child labour related reasons, such as herding, need to earn a living to help support the family and need to take care of siblings or other members of the family; migration or lack of dormitories, teacher of discrimination and systemic problems with the educational system. The understudied areas are physical and/or mental disabilities, lack of communication and socialisation skills, bullying or peer discrimination, and educational level of parents. Furthermore, the "initiatives to address the issue are considered palliative since they do not carry legal weight and do not provide sanctions against those who, in one way or the other, cause or made cause the dropping out of a child" (p. 7).

Moreover, it is also apparent that despite the effort of the Government, still the supply of education is so weak, especially in rural areas, that the Constitutional right to free compulsory education remains hard to achieve practically. As noted in del Rosario (2005), there are only 79 independent primary schools, which are mainly found in remote soums, and 232 independent schools with classes for eight years, consisting of primary and lower secondary schools.

The previous analysis of the reasons for dropping out of school has highlighted that poverty is a common factor in most cases of dropping out, which is likely to generate poverty traps. Poverty is behind the "economic reasons", but also the lack of motivation of many young people that declare that they "do not enjoy going to school" or that they "prefer to work" (or moved to work or helped with herding) rather than going to school. To exit the poverty traps it would be important to 
economically support the poorest children and their households. In most cases, this is the only way for them to escape the poverty trap.

Table 9 presents results of Logit estimates of the determinants of dropping out of school for the entire sample and separately for men and women. For the determinants of dropouts, we estimate by maximum likelihood a Logit model of the following type:

$$
\operatorname{Pr}(D=1 \mid X)=\frac{\exp \left(X^{\prime} \beta\right)}{1-\exp \left(X^{\prime} \beta\right)}
$$

where $D$ is a binary variable with outcome 1 in case of dropping out of school and $O$ otherwise; $X$ is a vector of regressors and $\beta$ is a vector of parameters; $\operatorname{Pr}$ denotes probability.

Dropouts are here defined as those individuals who have left school before completion of high secondary school not for normal causes, including having achieved the desired educational level. They represent about $35.76 \%$ of the sample, when including individuals that drop out of any type of school. The share shrinks down to $21.3 \%$ in the entire sample, of which $16.8 \%$ for women and $26.2 \%$ for men, when we consider only people dropping out of school before completing high secondary school. The higher share of dropouts among men is a consequence of the worse performance of men throughout the entire educational path.

Dropping out of school is expected to depend on individual and household characteristics. We include among the regressors such individual characteristics as age, civil status, having children, the fact of working while at school, the aspirations in life, and the place of residence; and such household characteristics as household income, the number of household members, whether both parents are living, as well as the father' and mother' level of education.

The baseline group includes: single men aged 25-29 years, with no children, belonging to a household whose income is greater than the Tugrik equivalent of $\$ 100$ and has three members or less, holding both parents with tertiary education and that did not work at school, whose main aspiration in life is being successful at work and living in Ulaanbaatar. 
Overall, the estimate is quite satisfactory. The pseudo- $\mathrm{R}^{2}$ is relatively high for this type of estimates, while in the meantime the model has a good predictive power, since it allows classifying correctly over $85 \%$ of the cases in all estimates, a high share.

There are no conditional gender differences in the probability to dropout: in fact, although ceteris paribus women have a probability of dropping out of school $56 \%$ greater than men, nevertheless the coefficient is not statistically significant. This finding is in contrast to that of unconditional estimates, with the gender dummy as the only explanatory variable: these estimates return an odds ratio for women, that is $44 \%$ lower than men' and statistically significant. This contrast between unconditional and conditional estimates suggests that men tend to have characteristics that correlate more with the probability of dropping out of school than in the case women.

The probability of dropping out of school is the lowest for the youngest segments, especially in the case of men. The group aged 15-19 years has less than half the chance of dropping out of school as compared to the oldest age group in the sample, used as a baseline. In the case of women, but not men, those aged 20-24 years have a $70 \%$ greater probability to dropout than their older counterparts. This finding might explain the recent effort of the Mongolian government and of the international organizations to reducing the school dropouts. On the other hand, it might suggest that the policy strategy actually adopted, and discussed above, has been not as effective as expected yet.

Civil status seems to affect only marginally the probability of dropping out of school: if anything, married men seem to have a greater probability of dropping out of school, although the coefficient is statistically significant only at a $10 \%$ significance level. Having children reduces the probability of dropping out of school in the case of women only, but seems to slightly increase it for men, although the latter coefficient is not statistically significant. This finding might be interpreted also the other way around to suggest that women who do not drop out of school tend to find a job more easily and therefore to establish a family and have children sooner.

The reason for these findings on civil status is probably to be found in the fact that, in most cases, the decision to drop out of school might have been taken earlier than that of marrying and / or having children. Unfortunately, the data does not allow distinguishing when each decision was taken. 
The variables measuring the household income provide evidence of the existence of poverty traps in place. Four income groups are considered: a) less than $\$ 30$ a month; b) between $\$ 30$ and $\$ 60$ a month; c) between $\$ 60$ and $\$ 100$ a month; d) over $\$ 100$ a month. These incomes categories are based on the Millennium Development Goals, which has set as an objective to provide at least $\$ 1$ or $\$ 2$ a day to each individual in the poorest countries of the world. Clearly, the estimates show that the household income influences the probability of dropping out of school in a highly significant way. The probability of dropping out of school is dramatically higher for the lowest incomes levels. More specifically, the poorest household income' segment has about 3.9 times the probability of dropping out of school of the baseline group. The group living out of $\$ 2$ and $\$ 3$ a month tend to have a probability of dropping out of school equal to 2 and 1.5 times that of the baseline group, respectively.

In addition, the impact of household income seems to be slightly more marked in the case of men for average income levels, and higher in the case of women for lowest income levels. In the case of women belonging to households living out of less than $\$ 1$ a day, the probability of dropping out of school is 4.1 times higher than that of the baseline group, against a comparable figure of 3.6 for men. In the case of men belonging to households living out of less than $\$ 2$ a day, the probability of dropping out of school is 2.4 times higher than that of the baseline group, against a comparable figure for women of 1.8 times.

\section{[Table 9 about here]}

Another useful proxy of the household wealth and therefore a way to test for the presence of intergenerational transfers is the number of household members. Controlling for the household income, the larger is the family the higher might the opportunity cost of education also be, which might force some young people in the family to drop out of school. We include different numbers of household members; the baseline household has 3 members or less; the households with more than 9 members have been grouped to avoid small cells. There is a continuous increase in the odds ratio with the number of household members increasing, although the variable becomes statistically significant in the case of households with at least six members. The odds ratio goes up until when the number of household members equals 8 . 
The impact of the number of household members is higher in the case of men than of women. It is likely that some men are sacrificed for herding, especially in rural areas, where herding is the only source of subsistence for many large households. The ceteris paribus odds ratio of a young person living in a household with 8 or more members is about 2.4 times bigger than that of the baseline of individuals living in households with three members or less.

Having lost their own parents increases the chances of dropping out of school in a highly statistically significant way for both genders. Confirming a finding that is common in the literature on the determinants of educational attainment in developing countries, the impact of being motherless is stronger than that of being fatherless. The reason is that mothers are closer than fathers to their children and therefore their impact on the educational performance of children is greater than that of fathers. The probability of dropping out of school is 4.4 times greater among motherless children and 2.6 times greater among fatherless children. In the case of motherless female children the odds ratio equals 9 .

Another channel through which the poverty trap might generate is the parents' educational background. There is a strong intergenerational transmission of human capital, or, in this case, of the lack of human capital that the educational system is unable to counterbalance in favor of the most talented individuals. This is typical especially of developing countries, due to the lower development of the educational system and its difficulty in equalizing opportunities for all. In the case under scrutiny, in fact, the educational level of parents dramatically affects the probability of dropping out of school of their children: the probability of dropping out of school is especially high in the case of parents with basic education or below.

Children of uneducated mothers are 9.8 times more likely to drop out of school than the baseline of children of mothers with tertiary education or above. In the case of female children, the comparable figure goes up to 16.5 . The data seems to confirm the aforementioned finding of a large literature according to which the educational level of mothers is ceteris paribus more important than that of fathers. 
Only less than $10 \%$ of the sample work while studying. It does not seem to affect from a statistical point of view, but in few cases, the probability of dropping out of school. Interestingly, having worked while studying tends, overall, to reduce (not to increase) the probability of dropping out of school. This is especially the case of young men working part-time, in services or in other types of work. This finding indirectly confirms the relationship between school abandonment and household income. Apparently, for some young people having worked while studying was an important precondition to continue their studies.

The aspirations of young people might be related to parents' education, but might also be innate. The SWTS allows catching some important aspects of the individual innate abilities and motivations, which may be taken as proxies of her talent and do not entirely depend on her family background. Answers to the question about the main aspirations in life of young people may catch these abilities. Providing information on this variable is an important asset of the SWT survey. The type of aspirations in life are a component of a young people "human capital" that does not always depend on education either, which suggests that they might correlate with some non-cognitive skills, a factor that recent research (Heckman et al., 2006) considers more and more important to explain previously unexplained aspects of a person' labor market success.

In these estimates, there seems to be a ceteris paribus correlation of some types of aspirations in life with the probability to drop out of school. Dropping out of school is associated with some goals in particular. It correlates positively with aspiring to gaining a reputation, to have a lot of money (especially for women), living freely (for men), and having a good family life (for men). Not surprisingly, the probability of dropping out of school correlates negatively with the aspiration to achieving a good education and making a contribution to the society. This can be taken as evidence that the aspiration to education should be supported as able to give not only a private return to the individual, but also a social return to the community as a whole.

Last, but not least, dropping out of school is much more common in rural areas, especially for men, who are involved in herding for a large share, up to $45 \%$. Young people living in rural areas have 6.8 times more chances of dropping out of school than their counterparts living in the capital 
city of Ulaanbaatar, which is the baseline. Living in a Soum centre means a greater probability of dropping out of school for men, but not for women. Instead, living in an Aimag centre does not seem to correlate with the chance of dropping out of school any more than living in the capital city.

\section{Educational marginalization}

Educational marginalization (EM since now) denotes the status of an individual that has an educational level sufficiently lower than average to feel like marginalized in the society in general and in the labor market in particular because of her/his educational gap. EM is clearly a country and age-specific concept, in as much as the threshold level of education that may lead to marginalization may change from one country, age and gender to another. EM might also assume a different meaning according to other factors, such as gender, the migration status and so on. It may or may not overlap with failure to oblige to compulsory schooling and dropping out of school. Whether those who drop out of (compulsory) schooling are EM depends on the average educational level of the group under consideration.

How to measure educational marginalization? Conventionally, we assume that those young people who are in the bottom $20 \%$ of the cumulative distribution of education attainment by years of education are EM. In order to get a more objective measure, we choose to include in the sample over which calculations are carried out all those individuals who declare that they are not studying any more, as based on answers to question C2 (“Are you studying now?").

Table 10 shows that the share of individuals aged 20-24 and 25-29 years with primary education or below is in Mongolia still very high. In particular, those with primary education or below are $10 \%$ of women and $18.5 \%$ of men in Mongolia. Women experience an educational advantage with respect to men: in fact, in their case, EM regards the individuals with basic education, whereas in the case of men, it regards individuals with primary education only.

\section{[Table 10 about here]}


The rest of this section focuses on the determinants of EM as defined in Table 11, which presents results of logistic regressions of the probability of being EM as correlated to such factors as age, gender, education attainment of fathers and mothers, household income and household size, the tendency to work while studying and other variables catching the individual and family background of young people. The table focuses on young people aged 25-29, which better represent the average level of education of the population in each country. The table presents odds ratio, computed by taking the exponential of the logistic regression' coefficients. Odds ratios measure the relative probability of the associated characteristics with respect to the baseline characteristics. Odds ratios cannot be negative, for obvious reasons. They can only be greater or smaller than one. When the reported figure is greater than one, it means that the given category has a greater probability than the baseline to be EM; a figure lower than one means a probability to be EM which is lower than the reference category.

The household' income is the key factor of interest. The impact of being born into a household living out of $\$ 1$ a day on the probability of being EM is about 2.5 times greater than that of being born into a household living out of more than $\$ 3$ a day.

The other factors that appear to be increasing EM include: being a woman, being a teenager, being a married and/ or divorced men, belonging to a large household, being motherless or fatherless, having their own parents with low education attainment (primary or below for men and low secondary education for women). Working while studying reduces the chances of EM and the effect comes especially from working in the service sector.

The declared goals in life seem also to be important correlates to the chance of being EM. The aspirations that tend to increase the chances of EM are: aiming to contribute to local community affairs, to make money, to establish a family, especially in the case of men, to gain a reputation or being free, especially for men. Instead, aiming to give a social contribution reduces the chances of EM.

[Table 11 about here] 


\section{Working poverty}

Employment itself is not always a way out of poverty, because, in fact, especially for young people, wages are, sometimes, so low that they fall below the poverty line. This gives place to socalled "working poverty" (WP since now), a common phenomenon especially in developing countries. The poverty line is defined as being equal to half the median labor income ${ }^{\mathrm{ix}}$. More specifically, although employed, those young people whose labor earnings are below the poverty line are considered to be poor, independent of whether their income is based on wage employment or self-employment.

Figure 1 provides the shares of WP (blue bars) and as a term of reference the share of households that fall under the poverty line as based on household income calculations (red bars) in the 8 countries where the SWTS has been collected. Unfortunately, household poverty cannot be computed but for half the countries in the sample, namely Azerbaijan, Egypt, Mongolia and Nepal. In the case of China, household income is available, but it is impossible to compute the poverty line due to the insufficient detail of the classification of incomes adopted. In the Chinese sample, no household falls below the poverty line, as over $60 \%$ of the sample is in the lowest class of income. The figure shows that Mongolia and China are the countries where the share of the working poor is higher: $28.4 \%$ and $27.3 \%$ respectively. Kosovo follows with a share as high as $21 \%$. In other countries, the workers who fall under the poverty line are lower than $20 \%$, with Nepal reaching the lowest peak at about $11.6 \%$.

It is worth noticing that WP among children reaches its highest share where also household poverty is the highest, namely in Mongolia. In Nepal and Azerbaijan, instead, household poverty is less common than low youth incomes.

In most countries, the phenomenon under consideration is not gender neutral, except perhaps for the case of China and Syria, where gender differences appear less noticeable. In all other countries, but Kosovo, the working poor are women much more frequently than men. Egypt is the clearest example of a female prevalence among the working poor: in this country, women have a share of working poor at about $31.7 \%$, just below that of female Mongolians. Nonetheless, the gender gap is 
in Mongolia (+7\% with respect to men) much smaller than in Egypt, where it reaches about 20 percentage points, by far the highest in the sample. Also in Azerbaijan gender differences are against women, with the gender gap in the share of working poor in favor of men reaching a high of about 10 percentage points.

It is also worth mentioning that gender differences are much smaller in terms of household poverty than in terms of youth working poverty. This is partly a consequence of the fact that gender differences do not show up across, but within household incomes.

\section{[Figure 1 about here]}

Several questions arise from the above descriptive analysis. What are, for instance, the determinants of working poverty? Is education a sufficient protection against the risk of falling into working poverty? What is the extent of the intergenerational transfer of poverty? Is there some kind of poverty trap at work? Is household poverty a cause of youth WP? What remains of this section will attempt to answer these questions by looking at results of logistic regressions of the determinants of working poverty in Mongolia.

Due to the specific nature of the data used in the analysis, only individual level variables are considered. Where possible, the following four groups of independent variables are included among the regressors, the same variables used to explain also the probability to dropout and to experience EM: a) the educational qualification of individuals; b) coming from a household living under the poverty line, to test the extent of intergenerational transfers of poverty: the coefficient of this variable can be taken as a test of the presence of poverty traps at work; c) family educational background; d) working while studying, location and other characteristics of the individual.

In Table 12, the overall significance level of the estimates is high, with a pseudo- $\mathrm{R}^{2}$ fluctuating between 0.43 and 0.58 . Correctly classified cases are always more numerous than $85 \%$ and the area under the ROC curve tends to over $90 \%$.

In simple estimates using only a gender dummy as a regressor, women appear to have a probability of experiencing low income jobs about 4 times higher than their male counterparts. The gender coefficient is statistically significant. When controlling for all the other regressors in Table 
12, instead, the gender dummy is not statistically significant any more, although the odds ratio increases by about a half, reaching almost 6 . The difference between conditional and unconditional estimates might depend on the characteristics of both genders and the tendency of women to have characteristics that are less frequently associated to working poverty as compared to men. This might explain why the sign of the gender dummy turns out to be not statistically significant.

Omitted estimates relative only to the group aged more than 24 years, when almost all individuals have reached their highest educational attainment, confirm findings relative to the entire sample both relative to the unconditional and to the conditional impact of gender on working poverty: the conditional estimates return a higher odds ratio, which is, however, not statistically significant.

Education provides quite an important defence against WP in Mongolia. This finding is generalized, since all odds ratios are lower than one, denoting a lower probability of individuals holding a given educational qualifications than that of the baseline holding basic education or below; nonetheless, not all coefficients are statistically significant in the case of men.

Not surprisingly, the higher is the educational level, the lower is the probability of falling into WP. Holding a general high secondary education diploma reduces by a half the probability of working poverty as compared to holding only basic education or below. This effect is quite similar across genders.

Vocational technical secondary education and specialized secondary education further reduce by about a third the probability of experiencing a low pay job. This effect is stronger for women than for men. The highest return is provided by tertiary education, but again not for men: tertiary education or above reduce the chance of working poverty down by about ten times the chances of basic education or below in the entire sample and by about twenty times in the case of women. This contributes to justify the tendency of young Mongolians to attribute much importance to tertiary education in their aspirations.

WP tends to disappear with time passing. It is less frequent among young people aged 25-29 years. The young teenagers, aged 15-19 years, are about two times more likely to have low pay jobs. In the case of men this impact is greater than among women. The difference of the young adults, 
aged 20-24 years, from the baseline is much less apparent: the former have just $30 \%$ more chances than the baseline.

Civil status seems not to be a statistically significant determinant of WP, although some civil statuses tend to be associated more frequently than others to WP. For instance, being a divorced, separated, widowed woman tends to be associated with a greater likelihood to be a working poor, whereas being a married man tends to reduce such likelihood. Also having children is not statistically significant, although men with children seem to be more likely, whereas women with children seem to be less likely to be working poor.

Confirming the presence of a strong poverty trap in place, the indicators of household poverty adopted are all associated with a greater chance of being a working poor, for both genders. It is sufficient to be in a family with a monthly income of between $\$ 60$ and $\$ 100$ to have a chance about three times bigger to experience low income jobs. The young people whose family earns less than $\$ 30$ a month have about 20 times the chance of experiencing low pay jobs as compared to the baseline of young people whose family earns more than $\$ 100$ a month. In the case of men, the likelihood is about 35 times bigger. This is a very strong impact that sounds as a warning in favor of policies aimed at supporting also financially the poorest segments of the Mongolian population.

Also other household characteristics are important determinants of the probability of experiencing WP. The number of household members increases the probability of being working poor almost continuously. This effect is stronger in the case of women, although it becomes statistically significant for very large families. The ceteris paribus odds ratio for living in a family with more than 9 members equals 3.1, a big effect. In omitted estimates, the household size has been included as a single variable: in this case, the odds ratio for a unit increase in the number of household members is about $30 \%$.

Having no father reduces by a half the likelihood to experience WP and having no mother also has an effect of reducing the likelihood of experience WP. This can b explained by the greater need for high income when the family financial support is missing. Parentless youth tend to search more actively for jobs that can provide sufficient financial support. 
Other parental factors, such as the educational attainment of mothers and fathers, seem not to be correlated to the probability to be in low pay jobs. Nonetheless, this seems not to be a consequence of the fact that other household characteristics are important, namely household income and number. In fact, omitted estimates where household income and household size have been omitted return roughly the same coefficients and significance level of parents' education.

Working while studying does not seem to affect in a statistically significant way the dependent variable either, although it tends to be associated with low income jobs more frequently in the case of women than men.

Young people aspirations do not seem to affect in a statistically significant way their chances to accept low pay jobs, but in the case of aiming at a good family life, which seems to increase the chances of WP. It is essentially a female effect, with an increase by 2.5 time of the chance of WP for women. The impact of other types of aspirations is not statistically significant.

Furthermore, the probability of WP is much lower in the capital city of Ulaanbaatar than in the Soum centres, but above all than in rural areas. There seems to be little difference between the capital city and the Aimag centers, or at least this difference is not statistically significant. Those young people who live in rural areas are 18 times more likely to be earning an income lower than the poverty line than their peers living in the capital city. This is especially a female effect, with women living in rural areas having about 70 times more chances of experiencing low pay jobs than women living in the capital city. This is also the consequence of the low productivity of jobs in rural areas, a consequence also of the dismantling of state-owned and cooperative large farms typical of the soviet times. The fragmentation of the set of machinery and other utilities and the property itself has much reduced the productivity level of agricultural activities in rural areas.

[Table 12 about here] 


\section{Summary remarks}

This paper studies the mechanisms through which the intergenerational transfer of poverty takes place. In other words, it considers household poverty a risk factor for youth poverty. Household poverty is caught by means of a number of control variables, such as holding an income of $\$ 1, \$ 2$, and $\$ 3$ a day, the number of household members and the educational level of parents. Youth poverty is seen as a multi-faceted phenomenon caught by such factors as: a) the probability of dropping out of school; b) the probability of being educationally marginalized; c) the probability of experiencing working poverty. Educational marginalization is defined as referring to individuals holding the educational level that the lowest $20 \%$ of the population holds; working poverty is defined as the condition of working for an income that falls below the poverty line.

The logisitic estimates of the odds ratio are based on a unique, nationally representative Schoolto-Work Transition survey carried out in 2006 in Mongolia, one of the 50 poorest countries of the world. The findings are rich of information regarding the risk factors of youth poverty. Weak household background seems to be associated with a high risk of poverty, hinting at massive processes of intergenerational transfers of poverty. All household characteristics appear to importantly affect the youth poverty status, suggesting that poverty traps might be in place. Nonetheless, one finding stands out. A young person born in a household living out of $\$ 1$ a day has a probability about 4 times greater of dropping out of school, 2.5 times greater of being educationally marginalized and 20 times greater of being a working poor than a young person born in a family living out of more than $\$ 3$ a day. This paper clearly suggests that special support should be provided to those young people who were born in households living out of $\$ 1$ a day. 


\section{Reference}

del Rosario, M., (2005) "The Mongolian Drop Out Study", Mongolian Education Alliance, Ulaanbaatar.

Government of Mongolia (2001), Interim Poverty Reduction Strategy Paper, Ulaanbaatar, June.

Heckman, J.J, Knudsen E. I. , Cameron J. L., J.P. Shonkoff (2006) "Economic, Neurobiological and Behavioral Perspectives on Building America's Future Workforce,” World Economics, JulySeptember.

Hertz, T., T. Jayasundera, P. Piraino, S. Selcuk, N. Smith, e A. Verashchagina (2007) "The Inheritance of Educational Inequality: International Comparisons and Fifty-Year Trends," The B.E. Journal of Economic Analysis \& Policy: 7(2: Advances): Article 10.

Lambert, P.J.; Lanza, G. 2006. "The effect on inequalities of changing one or two incomes", in The Journal of Economic Inequality, Vol. 4, No. 3, pp. 253-277.

Mearns, R. (2004), "Sustaining Livelihoods on Mongolia's Pastoral Commons: Insights from a Participatory Poverty Assessment", Development and Change, 35(1): 107-139.

Morris E. and Bruun, O (2005), Promoting employment opportunities in rural Mongolia, ILO, Bangkok.

UNDP (United Nations Development Programme) (2006), Human Development Report, Oxford University Press, Oxford. 


\section{Annex of Tables and Figures}

Table 1. Parents' occupation

\begin{tabular}{l|rr}
\hline & Father & Mother \\
\hline Administrative, managerial & 3.01 & 2.14 \\
Specialist & 3.91 & 6.59 \\
Engineering, technical and related & 3.45 & 1.29 \\
Clerical and related & 0.23 & 0.84 \\
Service worker & 4.83 & 8.79 \\
Agriculture and fishery worker & 0.33 & 0.31 \\
Production and sales worker & 1.75 & 1.67 \\
Machine and equipment fitter & 0.94 & 0.25 \\
Elementary work & 6.06 & 4.85 \\
Herdsman & 14.58 & 15.42 \\
Farmer & 0.2 & 0.17 \\
Retired & 15.25 & 21.28 \\
Self employed/own account worker & 9.46 & 9.77 \\
Unpaid family worker & 0.36 & 1 \\
Household duties & 1.82 & 6.72 \\
Unemployed/looking for job & 10.35 & 10.35 \\
Employed in overseas & 0.36 & 0.31 \\
Parent deceased & 18.55 & 6.11 \\
Other & 4.57 & 2.14 \\
\hline Source: own eaboration on the Mongo
\end{tabular}

Source: own elaboration on the Mongolian SWTS.

Table 2. Parents' education attainment

\begin{tabular}{l|rr}
\hline & Father & Mother \\
\hline Uneducated & 1.91 & 1.73 \\
Primary & 13.68 & 14.71 \\
Basic & 18.87 & 18.14 \\
Secondary & 27.44 & 26.84 \\
vocational technical education & 9.17 & 7.12 \\
diploma, specialized secondary & 13.86 & 18.52 \\
tertiary/bachelor & 12.71 & 12.12 \\
master's degree and above & 0.86 & 0.68 \\
& 1.49 & 0.15 \\
\hline
\end{tabular}

Source: own elaboration on the Mongolian SWTS. 
Table 3. Summary statistics on household's monthly net income (in '000 TUGs)

\begin{tabular}{l|rrrrrr}
\hline Variable & Obs & Mean & Median & $\begin{array}{l}\text { Std. } \\
\text { Dev. }\end{array}$ & Min & Max \\
& & & & & \\
\hline All & 6415 & 123.58 & 100 & 144.09 & 0 & 9000 \\
No zeros & 6367 & 124.51 & 100 & 144.23 & 1 & 9000 \\
From the $10^{\text {th }}$ to the $90^{\text {th }}$ (deciles) & 5153 & 109.77 & 100 & 51.68 & 35 & 236 \\
\hline
\end{tabular}

Note: As to the $31^{\text {st }}$ of May 2007, the nominal exchange rates of the TUG to the Euro and the US dollars were as follows: 1 Euro = 1566.8700 Tughrik; 1 Tughrik = 0.0006 Euro; 1 US Dollar = 1164.6993 Tughrik; 1 Tughrik = 0.0009 US Dollars.

Source: own elaboration on the Mongolian SWTS.

Table 4. Measures of inequality of the household's income

\begin{tabular}{l|rrrrr}
\hline Inequality measures & All & UB & $\begin{array}{r}\text { Aimag } \\
\text { Centres }\end{array}$ & $\begin{array}{r}\text { Soum } \\
\text { Centres }\end{array}$ & Rural \\
\hline Relative mean deviation & 0.1995 & 0.1788 & 0.2038 & 0.1971 & 0.1908 \\
Coefficient of variation & 0.4708 & 0.4146 & 0.474 & 0.4792 & 0.4918 \\
Standard deviation of logs & 0.4929 & 0.4609 & 0.5006 & 0.482 & 0.4651 \\
Gini coefficient & 0.2661 & 0.2378 & 0.2682 & 0.2669 & 0.2646 \\
Mehran measure & 0.3799 & 0.3506 & 0.3842 & 0.3752 & 0.3651 \\
Piesch measure & 0.2092 & 0.1814 & 0.2102 & 0.2128 & 0.2143 \\
Kakwani measure & 0.0638 & 0.0527 & 0.0651 & 0.0635 & 0.0624 \\
Theil index (GE(a), a = 1) & 0.1094 & 0.0886 & 0.1114 & 0.1102 & 0.1108 \\
Mean Log Deviation (GE(a), a = 0) & 0.1164 & 0.0977 & 0.1193 & 0.1141 & 0.1102 \\
Entropy index (GE(a), a =-1) & 0.1346 & 0.1166 & 0.139 & 0.1281 & 0.1189 \\
Half (Coeff.Var. squared) $(\mathrm{GE}(\mathrm{a}), \mathrm{a}=2)$ & 0.1108 & 0.0859 & 0.1122 & 0.1147 & 0.1208 \\
Atkinson inequality measures $(\mathrm{eps}=1)$ & 0.1098 & 0.0931 & 0.1124 & 0.1078 & 0.1044 \\
\hline
\end{tabular}

Note: The indices have been computed excluding the households whose incomes are lower the $10^{\text {th }}$ or above the $90^{\text {th }}$ decile.

Source: own elaboration on the Mongolian SWTS.

Table 5. Different measures of the poverty line (in Thous. TUGs)

\begin{tabular}{l|rrrrr}
\hline Relative Poverty Line & All & UB & $\begin{array}{r}\text { Aimag } \\
\text { centres }\end{array}$ & $\begin{array}{r}\text { Soum } \\
\text { Centres }\end{array}$ & $\begin{array}{r}\text { Rural } \\
\text { area }\end{array}$ \\
\hline Gini Benchmark Percentile & 63.31 & 61.89 & 63.41 & 63.35 & 63.23 \\
Gini benchmark income & 120 & 150 & 125 & 105.40 & 96 \\
Theil benchmark income & 109.77 & 124.86 & 113.52 & 100.55 & 89.11 \\
Deviation benchmark income & 123.31 & 137.67 & 127.90 & 112.70 & 99.50 \\
\hline
\end{tabular}

Note: The indices have been computed excluding the households whose incomes are lower the $10^{\text {th }}$ or above the $90^{\text {th }}$ decile.

Source: own elaboration on the Mongolian SWTS.

Table 6. Education level, by sex, age group, and urban rural

\begin{tabular}{l|ll}
\hline & $\begin{array}{l}\text { 15-29 aged } \\
\text { population }\end{array}$ & Of which: \\
\hline
\end{tabular}




\begin{tabular}{l|crrrrrrrr}
\hline & thous/ & $\%$ & Male & Female & $15-19$ & $20-24$ & $25-29$ & Urban & Rural \\
& & & & & & & & & \\
\hline Total & $\mathbf{8 0 8 . 8}$ & 1 & $49.4 \%$ & $50.6 \%$ & $41.6 \%$ & $31.3 \%$ & $27.1 \%$ & $55.0 \%$ & $45.0 \%$ \\
Uneducated & $\mathbf{2 7}$ & 3.3 & $68.7 \%$ & $31.3 \%$ & $38.3 \%$ & $40.2 \%$ & $21.5 \%$ & $19.2 \%$ & $80.8 \%$ \\
Primary & $\mathbf{9 7 . 2}$ & 12.0 & $58.0 \%$ & $42.0 \%$ & $45.7 \%$ & $28.7 \%$ & $25.7 \%$ & $24.1 \%$ & $75.9 \%$ \\
Basic (Grade 4-8) & $\mathbf{2 6 4 . 6}$ & 32.7 & $51.2 \%$ & $48.8 \%$ & $69.1 \%$ & $14.1 \%$ & $16.9 \%$ & $45.2 \%$ & $54.8 \%$ \\
Secondary (Grade 9-10) & $\mathbf{2 7 0 . 1}$ & 33.4 & $47.0 \%$ & $53.0 \%$ & $34.3 \%$ & $43.0 \%$ & $22.6 \%$ & $72.0 \%$ & $28.0 \%$ \\
Vocational technical education & $\mathbf{2 7 . 7}$ & 3.4 & $52.3 \%$ & $47.7 \%$ & $15.0 \%$ & $42.3 \%$ & $42.7 \%$ & $55.5 \%$ & $44.5 \%$ \\
Diploma, specialized secondary & $\mathbf{1 8 . 4}$ & 2.3 & $39.7 \%$ & $60.3 \%$ & $2.7 \%$ & $38.4 \%$ & $58.9 \%$ & $63.7 \%$ & $36.3 \%$ \\
Tertiary/bachelor & $\mathbf{1 0 0 . 7}$ & 12.5 & $38.8 \%$ & $61.2 \%$ & $1.9 \%$ & $41.4 \%$ & $56.7 \%$ & $72.1 \%$ & $27.9 \%$ \\
Master's degree and above & $\mathbf{3}$ & 0.4 & $37.5 \%$ & $62.5 \%$ & - & $12.5 \%$ & $87.5 \%$ & $87.5 \%$ & $12.5 \%$ \\
\hline
\end{tabular}

Source: own elaboration on the Mongolian SWTS.

Table 7. Education attainment by gender and place of residence (in \%)

\begin{tabular}{l|rrrrrrrrrrrrr}
\hline & \multicolumn{1}{|c}{ 25-29 } & \multicolumn{4}{c}{$15-29$} & \multicolumn{4}{c}{ Ages } \\
\hline & \multicolumn{1}{|c}{ Male } & Female Total Male & Female Total Male & Female Total & $15-19$ & $20-24$ & $25-29$ \\
\hline Uneducated & 4.64 & 2.06 & 3.34 & 3.46 & 1.94 & 2.65 & 8.05 & 4.88 & 6.43 & 3.07 & 4.29 & 2.65 \\
Primary & 14.11 & 9.98 & 12.02 & 16.05 & 7.34 & 11.4 & 38.98 & 22.36 & 30.5 & 13.18 & 11.01 & 11.4 \\
Basic & 33.94 & 31.53 & 32.72 & 22.96 & 18.12 & 20.38 & 41.1 & 35.77 & 38.38 & 54.29 & 14.7 & 20.38 \\
Secondary & 31.77 & 34.98 & 33.39 & 24.32 & 31.07 & 27.92 & 7.63 & 27.24 & 17.63 & 27.52 & 45.94 & 27.92 \\
Vocational technical & 3.63 & 3.23 & 3.43 & 5.8 & 5.07 & 5.41 & 0.85 & 3.66 & 2.28 & 1.24 & 4.63 & 5.41 \\
Diploma, specialized & 1.83 & 2.71 & 2.28 & 4.2 & 5.61 & 4.95 & 0.85 & 2.03 & 1.45 & 0.15 & 2.79 & 4.95 \\
Tertiary/bachelor & 9.79 & 15.06 & 12.46 & 22.22 & 29.45 & 26.08 & 2.54 & 4.07 & 3.32 & 0.56 & 16.49 & 26.08 \\
Master's degree & 0.28 & 0.46 & 0.37 & 0.99 & 1.4 & 1.21 & & & & 0 & 0.15 & 1.21 \\
Number of observations & 3,167 & 3,248 & 6,415 & 810 & 927 & 1,737 & 236 & 246 & 482 & 2,671 & 2,007 & 1,737 \\
\hline
\end{tabular}

Table 8. Reasons to leave school for the uneducated by age and gender (in \%)

\begin{tabular}{l|rrrrrr}
\hline & \multicolumn{1}{|c}{ All } & Men & Women & $15-19$ & $20-24$ & $25-29$ \\
\hline Failed examinations & 2.82 & 2.56 & 3.33 & 3.33 & 2.6 & 2.5 \\
Did not enjoy schooling & 26.55 & 26.5 & 26.67 & 23.33 & 27.27 & 30 \\
Do not like schooling & 2.26 & 3.42 & 0 & 3.33 & 2.6 & 0 \\
Wanted to work & 2.26 & 2.56 & 1.67 & 0 & 5.19 & 0 \\
Parents did not allow to continue school & 6.78 & 3.42 & 13.33 & 5 & 2.6 & 17.5 \\
Economic reasons & 9.04 & 11.11 & 5 & 20 & 5.19 & 0 \\
Takes care of livestock & 26.55 & 28.21 & 23.33 & 20 & 29.87 & 30 \\
Other & 23.73 & 22.22 & 26.67 & 25 & 24.68 & 20 \\
Number of observations & 177 & 117 & 60 & 60 & 77 & 40 \\
\hline
\end{tabular}

Source: own elaboration on the Mongolian SWTS. 
Table 9. Determinants of dropping out of school in Mongolia by gender (Logit estimates)

\begin{tabular}{|c|c|c|c|}
\hline Variable & All & Women & Men \\
\hline Women & 1.5633 & (omitted) & (omitted) \\
\hline \multicolumn{4}{|c|}{ Age group (baseline: Young old: aged 25-29 years) } \\
\hline Young teenager (aged 15-19 years) & $0.4527^{* * *}$ & $0.6182 *$ & $0.3519 * * *$ \\
\hline Young adults (aged 20-24 years) & $1.2378^{*}$ & $1.6989 * *$ & 0.9538 \\
\hline \multicolumn{4}{|l|}{ Civil status (baseline: single) } \\
\hline Married woman & 0.8314 & 0.9038 & (omitted) \\
\hline Married man & $1.6526^{*}$ & (omitted) & 1.523 \\
\hline Divorced, separated, widowed woman & 1.4841 & 1.6756 & (omitted) \\
\hline Divorced, separated, widowed man & 0.5871 & (omitted) & 0.4906 \\
\hline Man with children & 1.1613 & (omitted) & 1.1877 \\
\hline Woman with children & $0.5655^{* *}$ & $0.5122 * * *$ & (omitted) \\
\hline \multicolumn{4}{|l|}{ Household income classes ${ }^{\geq}$} \\
\hline \multicolumn{4}{|l|}{ (baseline is more than $\$ 100$ ) } \\
\hline From $\$ 60$ to $\$ 100$ & $1.5330 * * *$ & $1.5811^{* *}$ & $1.5441^{* *}$ \\
\hline From $\$ 30$ to $\$ 60$ & $2.0296 * * *$ & $1.8019 * * *$ & $2.3699 * * *$ \\
\hline Less than $\$ 30$ & $3.8510 * * *$ & $4.1203^{* * *}$ & $3.6441 * * *$ \\
\hline \multicolumn{4}{|l|}{$\begin{array}{l}\text { Number of household members } \\
\text { (baseline is } 3 \text { members or less) }\end{array}$} \\
\hline 4 & 1.0196 & 0.9985 & 1.0618 \\
\hline 5 & 1.113 & 1.249 & 1.0104 \\
\hline 6 & $1.3707^{*}$ & 1.1837 & $1.5401^{*}$ \\
\hline 7 & $1.5716^{* *}$ & 1.4427 & $1.7249 *$ \\
\hline 8 & $2.3631^{* * *}$ & $2.0269 *$ & $2.8781^{* * *}$ \\
\hline 9 or more & $2.0079 * *$ & $1.9899 *$ & $2.1081^{*}$ \\
\hline Has no father & $2.6100 * * *$ & $3.1482^{* *}$ & $2.0695^{*}$ \\
\hline Has no mother & $4.4310^{* * *}$ & $9.0158 * * *$ & $3.5079 * * *$ \\
\hline \multicolumn{4}{|l|}{ Father education (baseline: tertiary or above) } \\
\hline Uneducated & $3.1475^{* * *}$ & $2.7080^{*}$ & $3.4955^{*}$ \\
\hline Primary education & $2.2804 * * *$ & $2.2613^{*}$ & $2.1086^{*}$ \\
\hline Basic & $2.3453^{* * *}$ & $2.2034^{*}$ & $2.3080^{* *}$ \\
\hline Secondary & 1.381 & 1.2409 & 1.3632 \\
\hline Vocational technical secondary & $1.7586^{*}$ & 1.5415 & 1.721 \\
\hline Specialized secondary & 1.5007 & 1.857 & 1.2198 \\
\hline \multicolumn{4}{|l|}{ Mother education (baseline: tertiary or above) } \\
\hline Uneducated & $9.6755^{* * *}$ & $16.5055^{* * *}$ & $8.7084^{* * *}$ \\
\hline Primary education & $6.6310 * * *$ & $13.6128^{* * *}$ & $5.2242 * * *$ \\
\hline Basic & $4.8750 * * *$ & $11.0010^{* * *}$ & $3.3084 * * *$ \\
\hline Secondary & $2.3189 * *$ & $3.3401^{*}$ & $2.1452^{*}$ \\
\hline Vocational 32technical secondary & $2.1391^{*}$ & 3.1545 & 2.059 \\
\hline Specialized secondary & 1.5468 & 2.9026 & 1.2993 \\
\hline \multicolumn{4}{|c|}{ Worked while at school (baseline: did not work at school) } \\
\hline As a clerk & 0.5676 & 0.6434 & 0.6154 \\
\hline Part time & $0.1936^{* *}$ & 0.1594 & $0.2008^{*}$ \\
\hline
\end{tabular}




\begin{tabular}{|c|c|c|c|}
\hline In services & $0.0843^{* * *}$ & (omitted) & $0.1169 *$ \\
\hline In agriculture & 1.3544 & 0.7397 & 1.4678 \\
\hline As a commercial & 0.1288 & (omitted) & 0.413 \\
\hline Other types of work & $0.2508^{* *}$ & 0.4138 & $0.1785^{* *}$ \\
\hline Family run business & 0.3308 & 0.5876 & 0.2426 \\
\hline As a volunteer & 0.6131 & 1.1942 & 0.2974 \\
\hline \multicolumn{4}{|l|}{$\begin{array}{l}\text { Main goal in life* } \\
\text { (baseline: Being successful at work) }\end{array}$} \\
\hline Making a contribution to the society & $0.5832 * *$ & $0.5797^{*}$ & $0.5799^{*}$ \\
\hline Participating in community affairs & 1.4447 & 1.6893 & 1.3108 \\
\hline Upholding religious faith & 2.1298 & 1.4872 & 3.0329 \\
\hline Having a lot of money & $1.7202 * * *$ & $2.1276^{* * *}$ & 1.4707 \\
\hline Having a good family life & $1.3656^{* *}$ & 1.3895 & $1.3610^{*}$ \\
\hline Having a good education & $0.4301 * * *$ & $0.4707 * * *$ & $0.3980 * * *$ \\
\hline Gaining work experience & 1.4863 & 1.0553 & $1.9004^{*}$ \\
\hline Living meaningful and intended & 0.7885 & 0.7395 & 0.7775 \\
\hline Being self-confident and achieving goals & 0.8573 & 0.9111 & 0.7681 \\
\hline Gain a reputation & $2.7880^{* *}$ & $2.8735^{*}$ & 2.5856 \\
\hline Live freely & 1.6416 & 1.0998 & $2.1504^{*}$ \\
\hline To work in overseas & 1.1248 & 1.3855 & 0.9861 \\
\hline \multicolumn{4}{|l|}{ Location (baseline: Ulaanbaatar) } \\
\hline Aimag centre & 1.075 & 0.9702 & 1.1803 \\
\hline Soum centre & $1.6366 * * *$ & 1.412 & $1.7285^{* * *}$ \\
\hline Rural area & $6.8143 * * *$ & $5.0353 * * *$ & $8.8833^{* * *}$ \\
\hline Constant & $0.0134 * * *$ & $0.0119 * * *$ & $0.0179 * * *$ \\
\hline Number of observations & 6301 & 3145 & 3098 \\
\hline Number of dropouts & 1339 & 529 & 810 \\
\hline$\%$ of dropouts & 21.3 & 16.8 & 26.2 \\
\hline Pseudo-R ${ }^{2}$ & 0.377 & 0.367 & 0.379 \\
\hline Correctly classified cases & 86.1 & 0.88 & 84.7 \\
\hline Area under the ROC curve & 0.89 & 0.9 & 0.89 \\
\hline
\end{tabular}

Note: *significant at $10 \% ;{ }^{* *}$ significant at $5 \% ; * * *$ significant at $1 \%$.

Robust standard errors are computed using the Huber / White / sandwich estimator.

The table presents the odds ratio, attained by taking the exponential of the logistic regression coefficients: they measure the relative probability of the associated characteristics with respect to the baseline characteristics. When the odds ratio is greater than one, the associated characteristics has a higher probability of experiencing the outcome under consideration; vice versa, when the odds ratio is smaller than one, the associated characteristics has a lower probability of experiencing the outcome under consideration.

${ }^{¥}$ At the time of the survey, the exchange rate was: US\$ $1=$ Tugrik 1164.6993, and therefore: US\$30 = Tugrik 34940.979; US\$ $60=$ Tugrik 69881.958; US\$100= Tugrik 116469.93.

* Respondents are allowed to declare the three most important goals in their life. The variables in the estimates have been built taking into account only the first answer.

Source: own elaboration on the Mongolian SWTS. 
Table 10. The type of diploma that leads to educational marginalization, by age group and gender

\begin{tabular}{lllll}
\hline \multirow{2}{*}{ Country } & \multicolumn{2}{c}{ Age Group: 20-24 years } & \multicolumn{2}{c}{ Age Group: 25-29 years } \\
\cline { 2 - 5 } Mongolia & Men & Women & Men & Women \\
\hline
\end{tabular}

Note: the educationally marginalized are those young people holding a type of diploma that the lowest $20 \%$ holds. It means that we identify the lowest type of diploma that is possessed by at least $20 \%$ of the sample population. We only consider those individuals aged 20-29 years who are not students any more.

Source: own elaboration on the Mongolian SWTS.

Table 11. Mongolia: Odds ratios of the probability of being educationally marginalized (aged 2529 years)

\begin{tabular}{|c|c|c|c|}
\hline & \multicolumn{3}{|c|}{ Mongolia } \\
\hline & All & Women & Men \\
\hline Women & $11.9546 * * *$ & & \\
\hline \multicolumn{4}{|l|}{ Age (baseline: aged $25-29$ year-old) } \\
\hline Young teenagers (15-19 year-old) & $6.5422 * * *$ & $21.9641 * * *$ & $1.5709 * *$ \\
\hline Young adults (20-24 year-old) & 1.1885 & 1.245 & 1.1951 \\
\hline \multicolumn{4}{|l|}{ Civil status (Baseline: single) } \\
\hline Woman married & $0.5836 * * *$ & 0.8019 & \\
\hline Man married & $2.9461 * * *$ & & 1.3802 \\
\hline Woman divorced, separeted, widow & 0.7764 & 1.0639 & \\
\hline Man divorced, separeted, widow & $5.4443^{*}$ & & 1.5781 \\
\hline Man with children & 1.1676 & & 1.401 \\
\hline Woman with children & 0.9725 & $0.5891^{* *}$ & \\
\hline \multicolumn{4}{|l|}{ Poverty (baseline: more than $\$ 100$ ) } \\
\hline From $\$ 60$ to $\$ 100$ & $1.3682^{* * *}$ & $1.4105^{* *}$ & $1.3272^{*}$ \\
\hline From $\$ 30$ to $\$ 60$ & $1.5241 * * *$ & $1.6853 * * *$ & $1.4667^{*}$ \\
\hline Less than $\$ 30$ & $2.4366^{* * *}$ & $2.5334 * * *$ & $2.3829 * * *$ \\
\hline \multicolumn{4}{|c|}{ Number of household members (baseline: 3 or less) } \\
\hline 4 & $1.5152 * * *$ & $1.6279 * * *$ & 1.3501 \\
\hline 5 & $1.2554^{*}$ & 1.2509 & 1.3599 \\
\hline 6 & $1.4578^{* *}$ & $1.3868^{*}$ & $1.5533^{*}$ \\
\hline 7 & $1.4460^{*}$ & 1.3997 & $1.7580^{* *}$ \\
\hline 8 & $2.0826 * * *$ & $2.4562 * * *$ & $2.1472^{*}$ \\
\hline 9 or more & 1.4957 & 1.8528 & 1.421 \\
\hline Has no father & $1.5545^{* *}$ & $1.5448^{*}$ & 1.4731 \\
\hline Has no mother & $1.8475^{* * *}$ & $1.9200 * *$ & $2.2395^{*}$ \\
\hline \multicolumn{4}{|l|}{ Father education (Baseline: Tertiary or above) } \\
\hline Uneducated & 1.6586 & 1.4127 & 2.0616 \\
\hline Primary & $1.5808^{*}$ & $1.6697^{*}$ & 1.4283 \\
\hline Basic & $1.5797^{* *}$ & $1.7098^{*}$ & 1.3647 \\
\hline Secondary & 1.1082 & 1.0988 & 1.0179 \\
\hline Vocational tecnical education & 1.1891 & 1.508 & 0.9004 \\
\hline Specialized secondary & 1.1195 & 1.3499 & 0.7237 \\
\hline
\end{tabular}




\begin{tabular}{|c|c|c|c|}
\hline \multicolumn{4}{|l|}{ Father education (Baseline: Tertiary or above) } \\
\hline Uneducated & $4.9487^{* * *}$ & $3.1167^{* *}$ & $7.0653^{* * *}$ \\
\hline Primary & $3.4453 * * *$ & $2.8751 * * *$ & $4.6067 * * *$ \\
\hline Basic & $1.6536^{* *}$ & $1.8459 * *$ & $1.8904^{*}$ \\
\hline Secondary & 1.028 & 0.9689 & 1.2239 \\
\hline Vocational tecnical education & 1.2429 & 1.0263 & $2.0023^{*}$ \\
\hline Specialized secondary & 1.0369 & 0.9937 & 1.1762 \\
\hline \multicolumn{4}{|l|}{ Worked while studying } \\
\hline As a clerk & 0.692 & 0.2261 & 0.6111 \\
\hline Part time & 0.3425 & 0.2318 & (omitted) \\
\hline In services & $0.2161^{*}$ & $0.1345^{*}$ & (omitted) \\
\hline In agriculture & 2.8087 & 1.6546 & 2.0999 \\
\hline Other type of work & 1.5588 & 0.7369 & 1.0001 \\
\hline Family and business & 1.2927 & 0.466 & (omitted) \\
\hline \multicolumn{4}{|l|}{$\begin{array}{l}\text { Main goal in life* } \\
\text { (baseline: Being successful at work) }\end{array}$} \\
\hline Making a contribution to the society & $0.7038^{*}$ & $0.6665^{*}$ & 0.7473 \\
\hline Participating in community affairs & $1.8807^{* *}$ & $2.6651^{* *}$ & 1.3815 \\
\hline Upholding religious faith & 2.0762 & 2.0635 & 2.5151 \\
\hline Having a lot of money & $1.5592^{* *}$ & $1.8201^{* *}$ & $1.5440^{*}$ \\
\hline Having a good family life & $1.4178^{* * *}$ & 1.2679 & $1.5790 * *$ \\
\hline Having a good education & 0.9753 & 1.0041 & 0.8162 \\
\hline Gaining work experience & 1.1998 & 1.1871 & 1.478 \\
\hline Living meaningful and intended & 0.9071 & 0.914 & 0.9267 \\
\hline Being self-confident and achieving goals & 1.0759 & 0.9824 & 1.1683 \\
\hline Gain a reputation & $2.2819 *$ & 1.502 & 2.7022 \\
\hline Live freely & $1.7122^{*}$ & 1.1741 & $2.2597^{*}$ \\
\hline To work in overseas & 0.7862 & 1.0645 & $0.2644^{*}$ \\
\hline \multicolumn{4}{|l|}{ Location (baseline: Ulaanbaatar) } \\
\hline Aimag centre & $1.3320 * *$ & $1.6701 * * *$ & 0.9886 \\
\hline Soum centre & $1.9934 * * *$ & $2.5128 * * *$ & $1.4488^{*}$ \\
\hline Rural area & $4.9166^{* * *}$ & $6.0498 * * *$ & $3.7652 * * *$ \\
\hline Constant & $0.0036 * * *$ & $0.0897^{* *}$ & $0.0118^{* * *}$ \\
\hline Number of observations & 6280 & 3192 & 2976 \\
\hline Number of educationally marginalized & 575 & 1,392 & 1,967 \\
\hline$\%$ of educationally marginalized & 18.56 & 43.46 & 31.22 \\
\hline Pseudo- $R^{2}$ & 0.2944 & 0.3247 & 0.2212 \\
\hline Correctly classified cases & $78.93 \%$ & $77.73 \%$ & $82.49 \%$ \\
\hline Area under the ROC curve & 0.7972 & 0.8599 & 0.8204 \\
\hline
\end{tabular}

Note: *significant at $10 \%$; **significant at $5 \%$; *** significant at $1 \%$.

The table presents the odds ratio, attained by taking the exponential of the logistic regression coefficients: they measure the relative probability of the associated characteristics with respect to the baseline characteristics.

Robust standard errors are computed using the Huber / White / sandwich estimator.

Source: own elaboration on the Mongolian SWTS. 
Table 12. Logistic regression of the determinants of being a working poor in Mongolia

\begin{tabular}{|c|c|c|c|}
\hline & All & Women & Men \\
\hline Women & 5.7959 & & \\
\hline \multicolumn{4}{|l|}{ Education (baseline: Basic education or below) } \\
\hline Secondary & $0.4709 * * *$ & $0.4410 * *$ & $0.3971 * *$ \\
\hline Vocational tecnical secondary & $0.3597 * *$ & $0.2148 * *$ & 0.3603 \\
\hline Specialized secondary & $0.3089^{*}$ & $0.2272 *$ & 0.2211 \\
\hline University or above & $0.1289 * * *$ & $0.0647 * * *$ & 0.3827 \\
\hline \multicolumn{4}{|l|}{ Age (baseline: aged 25-29 year-old) } \\
\hline Young teenagers (15-19 year-old) & $1.9616^{* *}$ & 1.4038 & $2.2410^{*}$ \\
\hline Young adults (20-24 year-old) & $1.3827 *$ & 1.3533 & 1.3202 \\
\hline \multicolumn{4}{|l|}{ Civil status (Baseline: single) } \\
\hline Woman married & 1.0441 & 1.1417 & \\
\hline Man married & 0.6788 & & 0.6019 \\
\hline Woman divorced, separeted, widow & 2.7956 & 3.6039 & \\
\hline Man divorced, separeted, widow & (omitted) & & (omitted) \\
\hline Man with children & 1.4031 & & 1.5296 \\
\hline Woman with children & 0.8527 & 0.9351 & \\
\hline \multicolumn{4}{|l|}{ Poverty (baseline: more than $\$ 100$ ) } \\
\hline From $\$ 60$ to $\$ 100$ & $2.8887 * * *$ & $3.1810^{* * *}$ & $2.9506 * * *$ \\
\hline From $\$ 30$ to $\$ 60$ & $4.7311 * * *$ & $4.3032 * * *$ & $5.6383 * * *$ \\
\hline Less than $\$ 30$ & $20.0065 * * *$ & $14.6536 * * *$ & $34.8068 * * *$ \\
\hline \multicolumn{4}{|c|}{$\begin{array}{l}\text { Number of household members (baseline: } 3 \text { or } \\
\text { less) }\end{array}$} \\
\hline 4 & $1.6002 *$ & 1.0224 & $2.1747 * *$ \\
\hline 5 & 1.3834 & 1.4368 & 1.3995 \\
\hline 6 & $2.2536^{* *}$ & 2.0718 & $2.6753^{* *}$ \\
\hline 7 & $1.9897^{*}$ & $6.7037 * *$ & 1.3063 \\
\hline 8 & 1.6041 & $6.9019 * *$ & 0.5269 \\
\hline 9 or more & $3.0465^{*}$ & 0.8943 & $12.7132 * * *$ \\
\hline Has no father & $0.4813 * * *$ & $0.3839^{* *}$ & $0.5791^{*}$ \\
\hline Has no mother & $1.8 \mathrm{e}+04 * * *$ & 1.4358 & $1.1 \mathrm{e}+04 * * *$ \\
\hline \multicolumn{4}{|c|}{ Father education (Baseline: basic education or below) } \\
\hline Secondary & 1.0342 & 0.5816 & 1.8217 \\
\hline Vocational tecnica secondary & 0.6184 & 0.3861 & 1.0159 \\
\hline Specialized secondary & 1.4477 & 2.0803 & 1.1099 \\
\hline University or above & 0.746 & 1.0808 & 0.3402 \\
\hline Master & 1.3905 & 1.2716 & (omitted) \\
\hline \multicolumn{4}{|c|}{ Mother education (Baseline: basic education or below) } \\
\hline Secondary & 1.0199 & 2.2483 & 0.5756 \\
\hline Vocational tecnica secondary & $2.6489 * *$ & 2.8683 & 1.9212 \\
\hline Specialized secondary & 0.8465 & 0.9906 & 0.8126 \\
\hline University or above & 1.8444 & 4.248 & 1.0667 \\
\hline Master & 1.2672 & 3.6694 & (omitted) \\
\hline Education missing & $0.0001 * * *$ & (omitted) & $0.0000 * * *$ \\
\hline
\end{tabular}




\begin{tabular}{|c|c|c|c|}
\hline Working while studying & 1.157 & 1.3331 & 0.8176 \\
\hline \multicolumn{4}{|l|}{ Main goal in life (Baseline: being successful at work) } \\
\hline Making a contribution to the society & 1.4249 & 2.1163 & 1.2199 \\
\hline Participating in community affairs & 0.6725 & 2.4795 & 0.2294 \\
\hline Upholding religious faith & 0.8482 & 2.639 & 0.3794 \\
\hline Having a lot of money & 1.0387 & 2.8585 & 0.5966 \\
\hline Having a good family life & $1.6517^{* *}$ & $2.4783^{* *}$ & 1.2806 \\
\hline Having a good education & 0.9121 & 1.3565 & 0.8265 \\
\hline Gaining work experience & 0.738 & 1.8415 & 0.3558 \\
\hline Living meaningful and intended & 1.6959 & $7.6468 * *$ & 0.7276 \\
\hline Being self-confident and achieving goals & 0.864 & 1.4494 & 0.6046 \\
\hline Gain a reputation & 1.8441 & (omitted) & 1.0576 \\
\hline Live freely or wantonly & 0.7658 & 1.544 & 0.403 \\
\hline To work in overseas & 1.0578 & $11.5026^{* *}$ & 0.2888 \\
\hline \multicolumn{4}{|l|}{ Location (baseline: Ulaanbaatar) } \\
\hline Aimag centre & 1.8397 & 2.1449 & 2.2397 \\
\hline Soum centre & $3.3654 * * *$ & $6.3473^{* *}$ & $3.8476^{* *}$ \\
\hline Rural area & $17.9021 * * *$ & $69.5968 * * *$ & $11.0000 * * *$ \\
\hline Constant & $0.0066^{* * * *}$ & $0.0080 * * *$ & $0.0096 * * *$ \\
\hline $\mathbf{N}$ & 2150 & 1000 & 1140 \\
\hline Pseudo-R2 & 0.47 & 0.58 & 0.43 \\
\hline Correctly classified cases & $87.1 \%$ & $88.5 \%$ & $85.8 \%$ \\
\hline Area under ROC curve & 0.92 & 0.95 & 0.91 \\
\hline
\end{tabular}

Note: *significant at $10 \% ; * *$ significant at $5 \%$; $* * *$ significant at $1 \%$.

The table presents the odds ratio, attained by taking the exponential of the logistic regression coefficients: they measure the relative probability of the associated characteristics with respect to the baseline characteristics.

Robust standard errors are computed using the Huber / White / sandwich estimator.

Source: Own elaboration on the Mongolian SWT survey. 


\section{Figures}

Figure 1. The working poor by country and gender

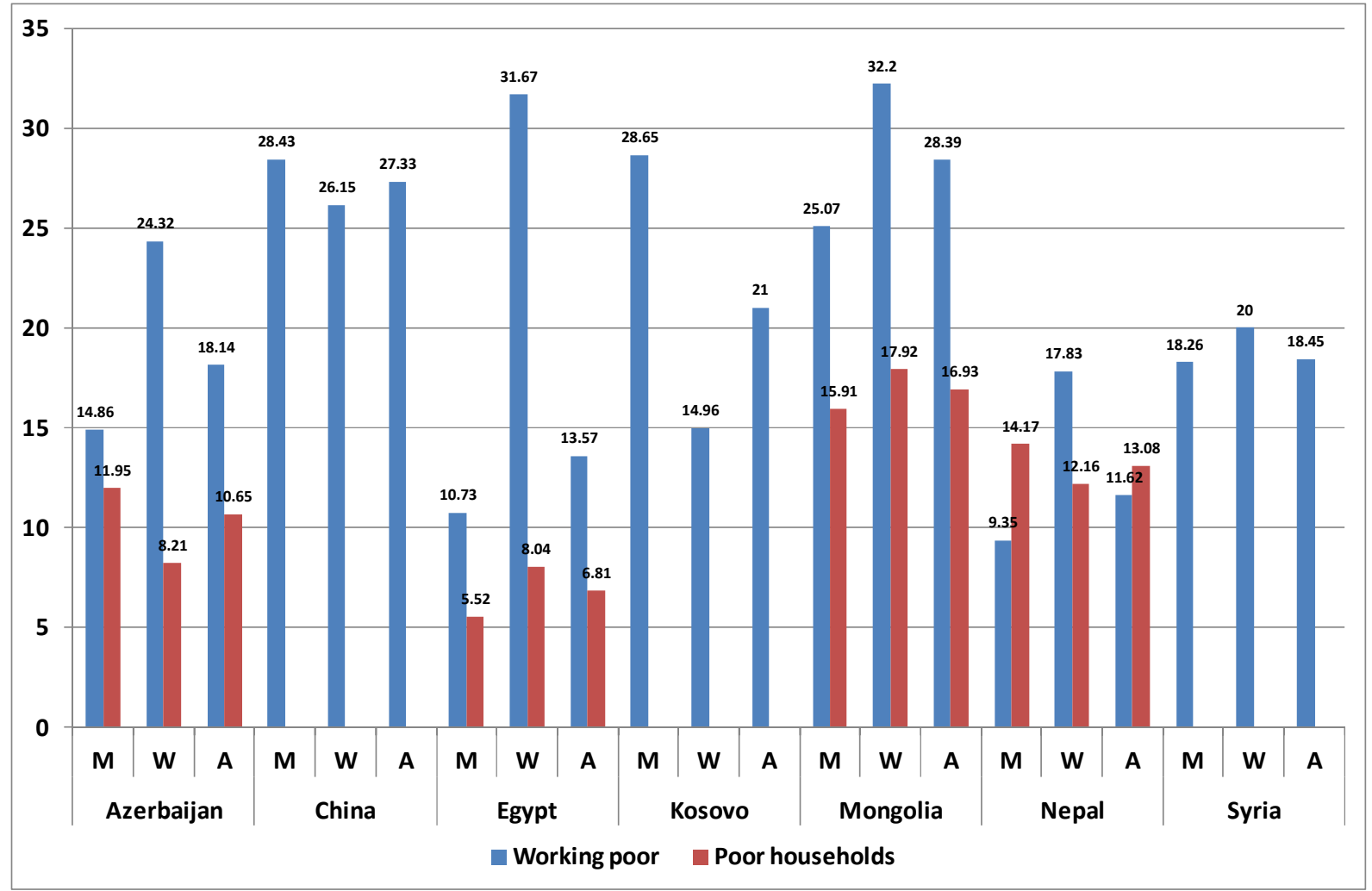

Note: "M" stands for men; "W" for women; and "A" for all.

Note: In the case of China it is impossible to compute the poverty line for households, due to the insufficient detail of the classification of household incomes adopted. No household in China falls below the poverty line.

Source: Own elaboration on the SWT survey of several developing countries. 


\section{Annex 1. The Mongolian educational system}

The Mongolian educational system has changed substantially as compared to the time of socialism ${ }^{1}$. The formal school system comprises primary, secondary, and higher education; pre-school education is also provided.

Although a 10 years of schooling general education system was inherited from the previous regime, and is still in place, the composition of primary, incomplete secondary and complete secondary education $(3+5+2$ structure $)$ has changed several times during the period of transition from plan to market. For example, the structure was changed into a $6+2+2$ model in 1990. In 1992, it was changed back to the 3+5+2 structure. However, since 1993, the system has adhered to the present $4+4+2$ structure: a) primary education ( 4 years, from age 7-11 years); b) basic or incomplete secondary school (4 years, from the age 11-15 years); c) complete secondary school (final 2 years, from age 15-17 years). Despite these reforms, though, the curriculum did not change.

Compulsory education ends at the age of 15 , when it is time to attain a diploma of noncomplete secondary education. Primary and lower secondary education together comprise the basic compulsory educational level that the State provides for free, as stated in the country's Constitution. General education includes a combination of basic education and high school (Law on Education, 2002). Also, the last two years of general education are free.

At the end of the first two stages, primary and lower secondary, graduates have two possibilities for high secondary school:

(a) general secondary school;

(b) technical and vocational school, and training, TVET.

Both graduates from incomplete and complete secondary education can join TVET, which further requires 2.5 and at least one year to complete, respectively. TVET comprises specialized complete secondary schools, as well as post secondary diploma programmes housed in higher educational institutions. Correspondingly, graduates from the former are given a complete secondary education diploma and those from the latter a technical specification diploma. TVET graduates have the possibility to access higher educational institutions.

Tertiary education comprises higher education diplomas and bachelor degrees. Institutions involved in higher education are of the following types: colleges, institutions and universities. The length of higher education is three years for the diploma programme (diploma of higher education) and four years for graduate programme (diploma of bachelor degree). However, for some professional courses, the length can vary (e.g. medicine). Graduates from universities and the 16 other higher educational institutions can obtain a diploma, a bachelor degree or a master degree. Some higher educational institutions are approved by the Ministry of Education to provide magistrate (two years) and doctoral programme (three or four years). Pre-doctoral and doctoral courses are offered in some universities. Non-formal and distance educational activities span over the entire system.

\footnotetext{
${ }^{1}$ For a more detailed analysis of the Mongolian educational system and legal framework, see Gerelmaa (2005) and del Rosario (2005).
} 
Annex 2. Variables definition

Table A2.1. Descriptive statistics

\begin{tabular}{|c|c|c|c|c|c|c|}
\hline Variable & Obs & Mean & Std. Dev. & Min & \multicolumn{2}{|c|}{ Max } \\
\hline Dropout & 6301 & 0.212506 & 0.409113 & & 0 & 1 \\
\hline Women & 6301 & 0.508332 & 0.49997 & & 0 & 1 \\
\hline Young teenager (aged 15-19 years) & 6301 & 0.417553 & 0.493195 & & 0 & 1 \\
\hline Young adults (aged 20-24 years) & 6301 & 0.311538 & 0.463159 & & 0 & 1 \\
\hline Married woman & 6301 & 0.151405 & 0.358471 & & 0 & 1 \\
\hline Married man & 6301 & 0.112046 & 0.315448 & & 0 & 1 \\
\hline Divorced, separated, widowed woman & 6301 & 0.005079 & 0.071089 & & 0 & 1 \\
\hline Divorced, separated, widowed man & 6301 & 0.000635 & 0.02519 & & 0 & 1 \\
\hline Man with children & 6301 & 0.882558 & 0.941048 & & 0 & 2 \\
\hline Woman with children & 6301 & 0.847961 & 0.89906 & & 0 & 2 \\
\hline \multicolumn{7}{|l|}{ Household income classes } \\
\hline From $\$ 60$ to $\$ 100$ & 6301 & 0.27456 & 0.446328 & & 0 & 1 \\
\hline From $\$ 30$ to $\$ 60$ & 6301 & 0.201873 & 0.40143 & & 0 & 1 \\
\hline Less than $\$ 30$ & 6301 & 0.095382 & 0.293765 & & 0 & 1 \\
\hline \multicolumn{7}{|l|}{$\begin{array}{l}\text { Number of household members } \\
\text { (baseline is } 3 \text { members or less) }\end{array}$} \\
\hline 4 & 6301 & 0.238534 & 0.426221 & & 0 & 1 \\
\hline 5 & 6301 & 0.20346 & 0.402604 & & 0 & 1 \\
\hline 6 & 6301 & 0.144422 & 0.351545 & & 0 & 1 \\
\hline 7 & 6301 & 0.079353 & 0.27031 & & 0 & 1 \\
\hline 8 & 6301 & 0.039994 & 0.19596 & & 0 & 1 \\
\hline 9 or more & 6301 & 0.02825 & 0.165698 & & 0 & 1 \\
\hline Has no father & 6301 & 0.184891 & 0.38824 & & 0 & 1 \\
\hline Has no mother & 6301 & 0.061101 & 0.239535 & & 0 & 1 \\
\hline \multicolumn{7}{|c|}{ Father education (baseline: tertiary or above) } \\
\hline Uneducated & 6301 & 0.015712 & 0.124368 & & 0 & 1 \\
\hline Primary education & 6301 & 0.109983 & 0.312893 & & 0 & 1 \\
\hline Basic & 6301 & 0.154103 & 0.361076 & & 0 & 1 \\
\hline Secondary & 6301 & 0.223298 & 0.41649 & & 0 & 1 \\
\hline Vocational technical secondary & 6301 & 0.07475 & 0.263009 & & 0 & 1 \\
\hline Specialized secondary & 6301 & 0.113633 & 0.31739 & & 0 & 1 \\
\hline \multicolumn{7}{|c|}{ Mother education (baseline: tertiary or above) } \\
\hline Uneducated & 6301 & 0.015712 & 0.124368 & & 0 & 1 \\
\hline Primary education & 6301 & 0.136169 & 0.342995 & & 0 & 1 \\
\hline Basic & 6301 & 0.170132 & 0.375778 & & 0 & 1 \\
\hline Secondary & 6301 & 0.251865 & 0.434118 & & 0 & 1 \\
\hline Vocational 40technical secondary & 6301 & 0.066815 & 0.249721 & & 0 & 1 \\
\hline Specialized secondary & 6301 & 0.175686 & 0.380583 & & 0 & 1 \\
\hline \multicolumn{7}{|c|}{$\begin{array}{l}\text { Worked while at school (baseline: did not work at } \\
\text { school) }\end{array}$} \\
\hline As a clerk & 6301 & 0.015077 & 0.121869 & & 0 & 1 \\
\hline
\end{tabular}




\begin{tabular}{|c|c|c|c|c|c|}
\hline Part time & 6301 & 0.020314 & 0.141084 & 0 & 1 \\
\hline In services & 6301 & 0.013807 & 0.1167 & 0 & 1 \\
\hline In agriculture & 6301 & 0.003333 & 0.057639 & 0 & 1 \\
\hline As a commercial & 6301 & 0.003333 & 0.057639 & 0 & 1 \\
\hline Other types of work & 6301 & 0.00619 & 0.078436 & 0 & 1 \\
\hline Family run business & 6301 & 0.006507 & 0.080409 & 0 & 1 \\
\hline As a volunteer & 6301 & 0.002857 & 0.053376 & 0 & 1 \\
\hline \multicolumn{6}{|l|}{$\begin{array}{l}\text { Main goal in life* } \\
\text { (baseline: Being successful at work) }\end{array}$} \\
\hline Making a contribution to the society & 6301 & 0.095858 & 0.29442 & 0 & 1 \\
\hline Participating in community affairs & 6301 & 0.024123 & 0.153444 & 0 & 1 \\
\hline Upholding religious faith & 6301 & 0.006824 & 0.082334 & 0 & 1 \\
\hline Having a lot of money & 6301 & 0.076655 & 0.266064 & 0 & 1 \\
\hline Having a good family life & 6301 & 0.1887 & 0.391301 & 0 & 1 \\
\hline Having a good education & 6301 & 0.199651 & 0.39977 & 0 & 1 \\
\hline Gaining work experience & 6301 & 0.026345 & 0.160172 & 0 & 1 \\
\hline Living meaningful and intended & 6301 & 0.017299 & 0.130393 & 0 & 1 \\
\hline Being self-confident and achieving goals & 6301 & 0.049357 & 0.21663 & 0 & 1 \\
\hline Gain a reputation & 6301 & 0.00619 & 0.078436 & 0 & 1 \\
\hline Live freely & 6301 & 0.017616 & 0.131562 & 0 & 1 \\
\hline To work in overseas & 6301 & 0.017616 & 0.131562 & 0 & 1 \\
\hline \multicolumn{6}{|l|}{ Location (baseline: Ulaanbaatar) } \\
\hline Aimag centre & 6301 & 0.169656 & 0.37536 & 0 & 1 \\
\hline Soum centre & 6301 & 0.223774 & 0.416805 & 0 & 1 \\
\hline Rural area & 6301 & 0.22425 & 0.417121 & 0 & 1 \\
\hline
\end{tabular}

Source: own elaboration on the Mongolian SWTS.

${ }^{\mathrm{i}}$ The Mongolian SWTS is of the same kind of similar surveys carried out in other developing countries in Africa, Asia and Europe, namely Azerbaijan, China, Egypt, Iran, Kosovo, Nepal, Syria. For further information, see http://www.ilo.org/employment/areas/WCMS_159352/lang--en/index.htm .

ii A second questionnaire (unused in this paper) gathers information from employers with the aim of determining the extent of demand for young workers and the attitude and expectations of employers when hiring them.

iii This is variable A9 of the questionnaire.

iv This statement is based on the assumption that the marginal utility of money is decreasing with income, like the marginal utility of any other good or commodity. This implies that assuming the same cost of investment in human capital formation, this cost will still be harder to bear for the poorer households.

${ }^{\mathrm{v}}$ For comparative purposes, it might be interesting to mention that Mearns (2004) reports the results of previous studies according to which $33 \%$ of the Mongolian population was living under the poverty line in the mid-1990s. The poverty line was based on the minimum required dietary intake assumed to be that of the bottom $40 \%$ in the income distribution.

${ }^{\text {vi }}$ Del Rosario (2005, p. 17-18) notes that up to 1.2 million Mongolians are involved in some program of adult learning. In addition, in coordination with the Ministry of Education, UNESCO programmes target also the illiteracy rate with the supply of courses additional to the formal ones provided by the Mongolian educational system. However, some observers fear that programmes of adult learning might increase the 
dropout rate in the long run, by allowing many adults with unfinished education to achieve the same degree as their pairs, but with less effort and above all with an insufficient level of knowledge.

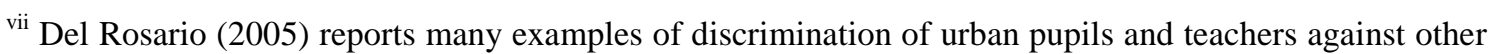
students coming from rural areas and/or from a poor family. The former consider that the latter pull back the class.

viii The plague of child labour and the ways to fight it are becoming a very hot issue in the agenda not only of international organisations and of national governments in mature market economies. Also national governments in developing countries become increasingly aware that child labour represents a trade-off between short time small advantages and long term important benefits.

${ }^{\text {ix }}$ Although often being very close to it, the poverty line should not to be confused with the $25^{\text {th }}$ percentile. 